\title{
At the Margins of the World: The Nature of Limits in Terrence Malick's The Thin Red Line
}

\section{ABSTRACT}

Terrence Malick's The Thin Red Line (1998) is an anti-war film which can be read as an Orphic narrative meditating on the relationship between humans and "nature." Many scholarly readings of the film have been attracted by analyzes that explore the influences of Cavell and Heidegger on Malick (Critchley, Furstenau and MacCavoy, Sinnerbrink). Kaja Silverman's recent opus, Flesh of My Flesh (2009), contains a chapter titled "All Things Shining." She elegantly examines how Malick's film explores the theme of "finitude." She argues that, ontologically speaking, human existence gains a more intense "glow" when humans are made aware of their mortality. The present becomes paramount. But like Orpheus, the present seeks to make amends with the past. Taking Silverman's analysis one step further involves exploring finitude through the film's many animal, arboreal and geological images. Nature can be read as a "margin" that more fully enhances the film's exploration of connection and finitude. To this end, the opening chapter of Jacques Derrida's Margins of Philosophy (1986) is invaluable. Entitled “Tympan," Derrida's introductory essay introduces a wealth of ecological metaphors. These stimulate an interaction between Silverman's model of finitude, Derrida's surprising ecologies at the margin and Malick's quest for what shines in all beings. 


\section{The POwer of Limits}

In Terrence Malick's magisterial third feature, The Thin Red Line (1998), an interpretation of James Jones's 1962 novel of that title, there is one especially striking scene. During the Guadalcanal campaign, World War II, an American battalion begins its assault on Hill 210; the fortress is controlled by Japanese soldiers. As Charlie Company makes its ascent amidst the exploding grenades, the war scene is interrupted by shots of the lush natural environment. There is a close-up of a bird chick struggling out of its shell. The newborn creature takes care of itself while the humans, unprotected, hurl themselves towards the treacherous hilltop. A soldier struggling along on his stomach nearly collides with a snake, which has business of its own. The Thin Red Line presents a continual mise-en-scène of natural environments which make their own thresholds with the human world. At first glance, nature may appear to be at the margins of the film's narrative of warfare. However, I shall argue that Malick's inscription of nature at the cinematic margins illuminates this work's central vision. ${ }^{1}$

By "central vision" I mean the audiovisual construction of the title and theme: there is a thin red line between life and death. Death defines limits and is perpetually at the margin of life. With this in mind, The Thin Red Line invites a dialogue with Jacques Derrida's concept of "margins." In "Tympan" (ix-xxix), the introductory chapter to Margins of Philosophy (1986), Jacques Derrida announces that limits are what make philosophy possible:

Being at the limit: these words do not yet form a proposition, and even less a discourse. But there is enough in them, provided that one plays upon it, to engender almost all the sentences in this book. $(\mathrm{x})$

In his chapter, Derrida experiments with limits by typographically dividing the page into two. The large chunk of text on the left-hand side carries the more philosophical discourse. This is complemented on the righthand side; its narrow margin is replete with mixed metaphors. Derrida typographically stages a philosophical discourse aware of its limits, placing it directly across from a margin which refuses such limits. From here, Derrida writes in poetic fragments. He introduces the mythological character of Persephone and places her in an environment thick with nature images

1 I would like to thank Dr. Laura Copier for her valuable responses to the first draft of this essay. 
and ecological metaphors. As the reader progresses, it becomes evident that the margins are indispensable; they may indeed be providing the essay's central thesis.

Malick's cinematic vision of nature forms the marginal "notes" which comprise his film's main theme. Private Witt (Jim Caviezel), who possesses most of the poetic voice-overs, wonders whether "all men got one big soul." But such a deep regard for communion comes at a price. What is required is a confrontation with the facts of human finitude. Philosophical, psychoanalytical and artistic responses to human mortality have been richly articulated by Kaja Silverman in her most recent book, Flesh of My Flesh (2009). Her chapter on The Thin Red Line, "All Things Shining," examines this theme by following a host of thinkers from Freud to Heidegger and Romain Rolland to Lou Andreas-Salomé. Silverman's introduction to the book reminds us that Heidegger goes back to the basics of "totality" and his abiding concern for "beings as a whole" (Silverman 11). My aim is to forge a deeper connection between the theme of human finitude and Malick's staging of nature as a force which teaches the power of limits.

To do this I shall engage a three-way dialogue between three works: Derrida's philosophical and poetic exploration of margins, Silverman's Heideggerian and psychoanalytic reading of Malick's aesthetics of finitude and The Thin Red Line. This film explores the margins between nature and the human condition by disabusing the human ego of status and selfinterest. Once shorn away, a "shining" remains. This emanates from what Private Witt conceives to be the "workings of one mind." For him, the collective soul involves a recovery of individual souls. Central to Silverman's study is one of the canonical myths about soul rescue, that of Orpheus and Eurydice. In an earlier chapter ("Orpheus Rex" 37-58) which follows the psychoanalytic work of Lou Andreas-Salomé, Silverman underlines how the latter theorized "recognition" of unconscious processes to be as crucial as their repression (48). She traces how Salomé's work centres on the human need to reach back and regain lost desires. Silverman stages Orpheus as that part of the psyche that goes on an unconscious journey to recover denied parts of the self; thus Eurydice personifies vital elements of the self that are stranded in the unconscious (58). In connecting Silverman's insights to Derrida's "Tympan," which focuses strongly on organs of hearing and the inner ear, it is important to recall that Orpheus is a musician. The sense of hearing becomes heightened in the shades of the underworld. Furthermore, in his marginal notes, Derrida introduces Persephone as a star actress. He enables her to shape-shift from goddess into elements of nature, ranging from images of conch shells to spirals, snails, coiled hair and the inner ear itself (x-xiv). Derrida's Persephone is musical and treads a dizzy underworld of vibrations. From here, listening can be 
external (outer ear) and internal (inner ear). Between these two anatomical areas are margins. In The Thin Red Line, the film's marginalia between nature and humans not only listen, they vibrate.

\section{DERRIDA AND THE INTIMATIONS OF NATURE}

The allegedly "main" text part of Derrida's "Tympan" offers a philosophical treatise that includes a biology lesson. Its topic is the ear, a vulnerable membrane made of a thin tissue which creates a margin between outer sound and inner vibration:

We know that the membrane of the tympanum, a thin and transparent partition separating the auditory canal from the middle ear (the cavity), is stretched obliquely (loxos). Obliquely from above to below, from outside to inside, and from the back to the front. One of the effects of this obliqueness is to increase the surface of impression and hence the capacity of vibration. It has been observed, particularly in birds, that precision of hearing is in direct proportion to the obliqueness of the tympanum. The tympanum squints. (xiv-xv)

Although it resembles a biology treatise, Derrida's passage mixes metaphors in its last sentence, the "tympanum squints." Organs for hearing also have a visual function. Audiovisual metaphors populate both sides of the page. The right-hand, narrower side of the page, that is, the margin which plainly "talks back" to the main text, may have a different topic and deploy different metaphors. These spin off into reflections on plants, insects, snail shells, and natural objects which look like spirals. All of these have their own audiovisual qualities. On this right-hand "margin" of the page, Derrida leads Persephone through her journey of metaphors. She becomes twirled into a "spiralled name ... a curved name" (xiii). Persephone's linguistic freight also includes an ability to pierce (xiv). She is capable of being "undulating" and "grassy" while also being associated with an insect, the "earwig" which, in turn, leads back full circle to the ear that can squint (xiv). Then to complicate the matter further, in Persephone's name there is the suffix of "phone." This is linked to the media of the "telephone" and the "gramophone" (xv). But Persephone's various names, mutually enfolding, belong to the marginal side of the page. Ergo, Derrida's marginalia argue that the ear itself is divided into yet more membranes: there are spaces beyond spaces, margins beyond margins, and such is the state of philosophy. In other words, Derrida's essay links the concept of margins to a mixed metaphor which interweaves many meanings: ears, auricular senses, vision, movement, nature, the underworld and the female gender in the form of Persephone. According to mythology, she is the goddess Core 
(Demeter's daughter) before being abducted by Hades, god of the Underworld; thus Core becomes Persephone and Queen of the Dead (Graves, The Greek Myths 89-90). Persephone has a paradoxical connection to both death and fertility. Demeter only agrees to re-fertilize the land if she can keep Core (Persephone) with her for nine months of the year (Graves 91). Persephone belongs to the Triad of Goddesses (Core/Persephone/Hecate) overseeing fertility. According to Graves, one translation of her name is "the ripe ear" (92). Thus in mythological terms, Persephone becomes ripe with connotations of death, the fecund and the aural. She becomes a site of vibrations, vegetation and natural cycles. Put more simply, all these different connotations which attach to Persephone, from sound, vision, nature and death, likewise attach to Derrida's concept of the margin(s).

Derrida's multiplex concept of the margins is uncannily present in the world of The Thin Red Line. The film will not be so obliging as to "illustrate" Derrida's splendour of circling metaphors. My exploration of contact between the spirals and repercussions in Derrida and the audiovisual ecologies of Malick's universe is to use the latter to critique the former. After all, Derrida only mentions death as an afterthought. It is as though he dashes off another scribble in the closing image of his introductory chapter with the words "some glorious cadaver" (xxix). Does he also seek what shines in death? It would take a number of steps to move from this glowing signifier of death to Silverman's analysis "All Things Shining." Cadavers suggest the opposite. But then the film's counterpointing of sound, image and "nature" enables me to make these steps towards Silverman. For between music, image and the natural environment emerges Malick's marginalia of primeval creatures and inspiring corpses.

The film's opening audiovisual image inscribes one such margin. Indeed, Malick can use the drawn-out long-shot of a crocodile to make a preemptive jot down the margins of the film's prologue. Before we can meet human characters, we must first meet the crocodile as it makes its way into a river. The creature gracefully punctures the surface algae. Here is atavistic, pure nature. To flick back to the margins of Derrida, I recall Persephone, who carries the freight of nature and its fecundity. As the crocodile disappears under the green surface, there is a sense of all that lurks below, invisible, waiting. What drives this image through its stately frames from the first moment of the crocodile's retroactive entrance (not from the water to the land but from land back to the water, an evolutionary backtrack) is organ music. One chord is sustained throughout the uninflected shot of the crocodile's descent into its green and watery underworld. The chord crescendos and this is what sets up Witt's opening monologue that raises the question: "What is this war in nature?" But the crocodile species, both atavistic and resplendent, has been here far longer than any human; it 
hardly strikes one as in a state of "war." After all, war is a human invention.

The first organ note is simple, all-encompassing and breaks through the margin that separates humans from nature. The opening chord and the crocodile's movements are not interrupted by montage editing. The chord could come from inside the crocodile as well as from the vibrations of our inner and "visual" ear. This means that the sound actually permeates the threshold between inner and outer cognition, between human psyche and natural environment. This audiovisual signifier also dissolves the boundaries between now and the atavistic past. As a musical instrument, the organ signifies time ancient and historical. The organ chord thus testifies to the crocodile's hereditary rights and longevity. The crocodile can also be read as a signifier for evolution and the cycles of life and death. The crocodile will feed, fornicate and die.

Humans also have a cycle of life. But the human experience of the moment can be undone by memory. When Witt has gone AWOL on one of the Melanesian Islands, his experience of blissful communication with the swimming children, their mother, the fishermen and the gorgeous landscape, will be both punctuated and punctured by older memories in the form of a scene insertion which comprises Witt's reminiscence of his mother's death. He confesses that he saw nothing elevating in the way she passed on, but hopes one day to leave life with her dignity. In other words, his memories of his mother's death offer a marginal remark that will become important to Witt's eventual death at the hands of a Japanese battalion; he faces this moment with dignity, and even after death his voice-over will return. The crocodile's opening chord will find its closure in the human voice. The evolutionary journey has been made, and death faced with acceptance. Between each step along the journey, the task has been to connect human to human, homo sapiens to nature.

Silverman emphasises throughout her book that surrendering to the knowledge of death is what allows us to acknowledge our similarities to each other. This is a tall order. Facing death means facing finality. The crocodile is precisely that: the atavistic flesh from which we come, the primal DNA from which we will be extinguished. The audiovisual image of the crocodile is a cunning piece of marginalia. There is no sense of connection or aspiration to moments of bliss and wholeness without that perpetual and monotone vibration. The vibration is the reminder of annihilation. To scribble a note back to Derrida, when we perforate the threshold line between a raw nature (that which reminds us of mortality) and our human, emotional sense of connection, it is not the cadaver we will seek. Attention should be rather paid to those edges between life and death. In Malick's film, the shots that visualise Witt's mother dying with dignity hinge on the paradox that we do not see the actual moment of her death. Rather, we 
hear her heart beating. The camera tracks away from this to the image of the caged birds in her bedroom. The bird as soul has not yet escaped the physical cage. The images that hold sway assert life as most present when it touches the membrane between life and death, stretching it out to its full extent.

Importantly, this idea of a membrane that is punctured is only one part of the complex arsenal of metaphors that Derrida offers. In the first citation I chose (above), one of the words that he uses to refer to the construction of the auricular canal is "obliqueness." This word pinpoints the image of a plane that is neither horizontal nor perpendicular to another. Things oblique lie at odd angles to each other. The passage I quoted from Derrida ends appropriately with the phrase "the tympanum squints." This is exactly what an oblique plane would do if it had eyes to behold the object of its gaze. To take Derrida one step further in this direction, I would argue that marginalia work obliquely. They do not look straight back.

The gaze is not returned eye to eye, but with a sensitive squint. Just before Witt makes his final journey through the stream to decoy a Japanese battalion, there is a close-up of the head and body of a large, fluffy white owl. The owl is watching. It is surrounded by encroaching soldiers. The owl is sentient to the rustle in the trees; there is a ruffle of air through its feathers. The owl may be looking on, but it does not look straight into the camera. There is no shot-reverse-shot between owls and humans. Such a shot would give the owl its own footnote. It would be looking "wisely" or presciently at the human warriors. But Malick refuses us the consolations of the shot-reverse-shot. Thus he disabuses us of the comfort of a mythological creature who is keeping its fairy-tale eye on us, looking out for us, like some spirit who knows the meaning of life. This is far from the case. The owl leaves us with its wink delivered along an oblique angle. Here, the odd effect is that the owl is watchful yet indifferent. It sees but does not judge. The owl avoids our anthropomorphizing tendencies. Similarly, when the Americans capture a crocodile, strapping it down, poking it with a stick, it winks too, but neither at the soldiers nor us. When Witt realises that there is real danger in his position, he looks at a collection of bats suspended from the trees. They could be eyeing him up or not. But then, they are bats. It is their sonar skills that make them aware of Witt's presence. They are actually looking at him from a position of feral sensitivity. They also gaze at him obliquely. All these oblique winks, squints and looks from the natural world present opaque marginalia.

It would be easy to project a host of interpretations onto nature's sideways and often auricular, sensory glances. In The Thin Red Line, the oblique look of animals decomposes a gaze that would analyze. In fact, the spectator's powers of analysis are softened by the touch of sensory vibra- 
tions. Wind subliminally ruffles the owl's feathers and the leaves of trees as they catch the light. What shines also makes itself heard. The margin between nature and sound captures Persephone before she again disappears into an underworld where, as Orpheus discovers, to even risk looking back just once can have disastrous consequences. Perhaps Malick's film draws us into a state of experiencing nature as an invisible margin where the underworld and death are always present. But while they cannot always be clearly seen, they can be heard. In his essay, Derrida has a passion for peering into the canals of the ear. To recall his mixing of metaphors, he associates Persephone with phones and gramophones. Quite differently, Malick keeps us listening and watching without the fetishes of endlessly turning metaphors. Malick's cinematic poetics is consistent and economical in the way it fuses and separates its main and marginal audiovisual texts. In Derrida's intimations of nature, the spiral, the insect and the bird will dovetail into an ecology of metaphors, full of Derrida's fabricated creatures and media machines. In Malick's world, however, nature is both world and underworld. Nature and animals and the endless trees and grasses which incubate the soldiers and which will also be their killing fields stubbornly refuse to be co-opted into an excessive range of metaphors. Yet, as Silverman's exquisite analysis of the film argues, it will constantly remind us of the vicissitudes of place and psyche, and place as psyche.

\section{ORPHEUS SHINING}

Silverman's analysis of The Thin Red Line relies on her reading of the Orpheus / Eurydice myth through the lens of Lou Andreas-Salomé's work. Silverman cites Salomé's profound experience as a young girl who, in her childhood garden, confronts her first experience of finitude. As a result, argues Silverman, Salomé "gained psychic access to the limitlessness of being” (27). Salomé works with Freud during a time when he is immersed in those troubling texts, The Future of an Illusion (1929) and Totem and Taboo (1913). It is in these texts that Freud theorizes the existence of a death drive; he must consider how it can connect to his other models, most notably the Oedipus Complex. Salomé's own approach to the double dynamic of the Oedipus complex and finitude took another turn. Silverman reads Salomé's Looking Back (1951) as a linking of Oedipus with Orpheus. Anyone taking the psychoanalytic journey will have to separate from the primary beloved(s). But for Salomé, the therapist's work needs to do more than have the patient merely let go of the past. Instead, he or she must be encouraged to regain a connection to what has been lost. In Salomé's work, reclaiming that past, even in part, provides the grounds for healing. Not only do patients experience a richer part of their "re- 
claimed" personal unconscious, but they can also win back pieces of their historical and collective unconscious (Silverman 45-47).

Here, a sense of connection between past and future can enable a larger sense of "being." When Silverman gets to her chapter on Malick, Salomé's art of looking back is then read in intimacy with Romain Rolland's celebrated work on "oceanic feelings" (124-25). Heidegger enters the stage when the concept of "looking back" is interwoven with the task of looking beyond the individual unconscious. When this happens, when finitude is faced, "we" can gain a deeper sense of connection to the greater "whole." Heidegger's question about poets ("What are Poets for"), published one year after the end of World War II, asks what drives humans to the historical horrors he has witnessed. Malick's Witt will ask the question: "What is this war at the heart of nature?" Heidegger wants to consider the uses of poetry in a "destitute time." This question leads to the act of facing the disturbing sides of human "nature." Humans threaten themselves when they refuse to give up the desire to be assertive in everything. Humans need to learn to surrender. When they refuse, they act in destructive ways. Destruction jeopardizes any sense of deeper connection. In such times, the poet can come into her or his own, for the poet's job is to shed light on finitude and allow us to grapple with the transience of the human lot.

The undercurrent of Silverman's project in "All Things Shining" is to take Heidegger, Salomé, Romain Rolland's notion of "oceanic feelings" (Parsons 174), and blended versions of the Orpheus and Eurydice myth and allow them all to converse with The Thin Red Line. Silverman underlines how Malick almost coaches his characters in the art of being disempowered so that they can learn the power of limits. This surrender requires a loss of narcissism. Silverman details individual characters: Witt, Bell, and the cynical Sergeant Welsh, who feels most alone "only with other people." Silverman tracks them sensitively on their journey through $\mathrm{Ha}$ des. Here they might catch glimpses of what they lost long ago. They will all be robbed of illusions that block the flow of oceanic feelings, or what Witt calls the "one soul." Here, my concern is to take Silverman's concept of finitude one step closer to Malick's poetics of nature. Indeed, to do this means staging a meeting between Silverman's Eurydice and Derrida's Persephone.

Derrida's Persephone and the phonic meanings that cluster around her name lead into a cavernous yet lush underworld. Indeed, Persephone occupies a soundscape. Like some vicarious Hades, Derrida relegates her to "grottos, to chasms, to all the pockets hollowed out of the terrestrial crust whose emptiness makes them into resonating drums for the slightest sounds" (xvi). Derrida is on a roll with his conceptual metaphors of space, as it is "the deep country of hearing, described in terms of geol- 
ogy" (xvi). Even Derrida's metaphors for anatomy are made of the stuff of place, when he refers to the "cartilaginous cavern" (xvi). Keep in mind too that, for Derrida, the inner ear at the end of the auricular canals is also a margin. Furthermore, Persephone comes to signify a cavern of sound. Thus she becomes the margin itself, ingrained in geology, earthy and soiled by those chasms dug out of the ground.

The Thin Red Line is subtle and consistent in a cinematography which is aligned to the ground, soil and what lies under the earth. There are frequent shots of the canopy of trees and light which are filmed from a position on the ground. During the crucial hill battle, the camera's POVs and even those shots which operate out of the POV axis are grounded deep in the grass. As spectators, we are drawn repeatedly into looking at the world from our stomachs and on our knees. We have grass and soil in our faces. Soldiers crawl. At the hill's bunker, Japanese soldiers are smoked out of burrows and humiliated as they squirm through the smoking geology of the landscape. The Americans reach the Japanese Bivouac, where the combat will involve guns and bayonets; as they do, Captain Stavros's voice-over becomes the guiding monologue. Relieved of his duty because he wanted to save his men's lives, Stavros's voice-over accompanies Witt as the latter looks down at a Japanese corpse. There is one shot of this cadaver's face looking up, mist descending, his gaze oblique. The rest of his body is trapped under the cavernous ground. Everything Stavros says offers a tender margin to the relentless visage of the death mask: "Are you righteous? Kind? . . A Are you loved by all? Know that I was too. Do you imagine your sufferings will be less because you loved goodness, truth?" Many of the monologues ask similar questions, being both personal and universal in their scope. Yet the scope of this possible "you" is never specified. Indeed, the "you" could refer to the dead soldier before he joined the army, active in his civilian world. Was he righteous, kind, loved by all? He was certainly not going to escape suffering. The poetic repetition of "you" repeatedly hails the "other" that metonymically can dwell within the phrase "all of us." We are linked to the Japanese soldier by common humanity. One day we will all be cadavers and return to the earth. The phrase "Are you loved by all?" touches on the oceanic feeling that Silverman refers to throughout her study. Yet there is an extra twist. The dead soldier's body is in the cavern, the underworld. He is already fused with nature. To conjure Derrida's Persephone, she possesses the dead. The cutaway to the shimmering trees, again, consistently filmed from ground level, reminds us of the embrace of death. Perhaps between the margins where Persephone meets Malick's vision of nature, the Freudian death drive creeps in. One wonders whether nature takes the role of both Persephone and Hades, ready to collect soldiers like male Eurydices. 
In her first two chapters, Silverman emphasizes that the Orpheus / Eurydice narrative is a heterosexual myth (117-20). Silverman gives the examples of Witt's mother and his stay with the Melanesian people as traces of Orphic myths. But I will draw out her examples with the following observations. Witt's mother takes a double role, as she is both Oedipally connected to him and may yet be one shadow of Eurydice. In the film's early scene which follows Witt's idyll with the Melanesian peoples of the Solomon Islands, he is drawn to a mother and her children. Hypothetically, they could be Witt's new family, he being the father, his Melanesian wife holding their child. The paradise is pre-Orphic, pre-separation and, indeed, pre-Oedipal. Later in the film, Malick will have his character Witt live out an adult's cares. When Witt returns to a scene with another set of villagers, he must face images that dismay him, from quarrelling brothers and frightened children to a shelf of sinister looking skulls. Are these skulls Japanese or American or Melanesian or simply revered ancestors? Whatever their source, they are reminders that death awaits. These many faces are lined up along a thin red line.

In Silverman's reading of Salomé's work another thin line appears. Orpheus and Eurydice can be analyzed as two sides of the same psyche (45). Orpheus is the side of a human that must turn backward to find a Eurydice who may be far more than one individual. I would take Silverman's insights one step further. Orpheus Rex is woman or man or even a social collective (as Silverman also alludes to in her reference to Benjamin's celebrated Angel) that must look into an unconscious, both individual and social, to grasp the finality of loss, of death, and the necessity of living vitally. The movement back towards an unconscious that is greater than that of an individual will meet a Persephone on the margins of deathly nature.

In The Thin Red Line, nature as a deathly space is rooted in the earth. Appropriately, when Witt does consummate his wish to die with dignity, his comrades bury him in the earth. Now, the dignified Orpheus Rex joins his dignified mother, with all these parts of the psyche merging with the film's final voice-over. His voice will be a synecdoche for untold voices, and as he (and they) speak, the camera tracks back through water, air and sky. Orpheus Rex travels through nature and cannot avoid Persephone. According to Derrida, Persephone is linked to the "phone" in phonetics, and by association, the human voice. Persephone is entirely absent from Silverman's index of proper names, and Derrida has no use for Orphic vibrations in the inner ear of his essay. Caverns are ill-lit and full of sound. Yet nature, when Persephone comes above ground, is all shining. Indeed, perhaps Persephone is also Eurydice's paramour. 


\section{To End it All: The Thin Green Line}

Eurydice and Persephone both occupy the underworld, while Persephone can spend part of the year above ground. The underworld is not a separate space, but is an overlapping terrain that acts as a powerful margin for the "upper" world. If one connotation of the underworld in The Thin Red Line is nature, then it is trees, earth and animals that provide the site in which life and death are staged, in which nature as death is the margin for nature as life. But more than this, Witt's pantheistic visions of the connection between humans and nature underline how the "one big soul" is itself the stuff of nature. The thin red line between life and death runs obliquely to many thin green lines. Following Derrida, these margins of green lines that invisibly mark the boundaries between humans and nature are everywhere, yet are nowhere easily found. After all, without a margin there would be no opportunity for that boundary to perforate, change shape or overlap with other fleshy and arboreal membranes. Within Malick's frame, the Japanese soldier's face, emerging from the earth, is also a poetically repeated POV shot of the shining trees. In other words, the dead have a gaze, and so the thin red line between life and death is also the thin green line. In other words, anything that connotes the earth, its caverns, the trees, animals, water, sky and, in fact, the full range of what is now referred to as biodiversity is itself a margin. Derrida subtly theorises that marginalia are somehow cleverly central in their contributions. In Malick's film, all that is natural is indeed central to the cinematic frame; yet all that is natural cunningly camouflages its true powers.

In his introduction to the BFI study book, devoted entirely to Malick's film, Michael Chion provides us with an important insight into the function of the "frame" in cinema. According to Chion, one of the triumphs of The Thin Red Line is its ability to deliver on the following aesthetic remit: "Cinema is the art that makes it possible to place the large and the small things of this world on the same scale, making them figure at the same size in the changeless form of the screen" (9). Derrida's work on marginalia argues for subverting the notion that the main part of the text is not to be read as less important than the margin. The cinematic screen makes small and large scales co-determinate. The screen enables the marginal or small or less focused within the frame to be perpetually present. Hans Zimmer's music is a crucial component throughout all the sequences. The film's first chord is more than a motif for the crocodile. After all, no musical harmony would be possible without the appropriate base notes. The first chord could be described as the film's first primal sound around which many other sounds and sound effects will evolve. When the soldiers as- 
sault the hill, sound effects in the form of thunderous explosions are what debilitates and terrifies. The camera that is submerged in the grass often frames the soldiers with grass around and through their faces. The grass runs obliquely to their expressions, but is a reminder that the collective of faces is inescapably part of nature.

In the film's epilogue, the POV of this collective of faces, bodies and resonating nature becomes the site from which the camera will look as it sails away from the Solomon Islands. Witt's voice-over implies a soul speaking out towards water and land. This "voice" is made of myriad souls. He refers to a "you" which is both the individual and collective soul. Perhaps this spiritual centre speaks out to nature from a position difficult to trace. The monologues might emerge from where Eurydice and Persephone meet and then separate. There is an oblique cross-over between thin and green red lines, cutting through the collective "we." Silverman is very specific in her interpretation of Witt's last lines: "Look out through my eyes. Look out at the things you made. All things shining." Silverman catches the "all" as both "earthly" and "diverse" (132). The "all" and its manifold connections offer no easy solutions. There are no spiritual power grids to keep everything in some comfortable state of homeostasis. The "all" is an infinitely turning, disappearing space between marginal worlds. And these co-exist with difficulty. They require the perpetual interventions of mortality.

\section{WORKS CITED}

Andreas-Salomé, Lou. Looking Back: A Memoire. New York: Marlow, 1995. Print.

Derrida, Jacques. Margins of Philosophy. Trans. Alan Bass. Chicago: Harvester, 1986. Print.

Chion, Michael. The Thin Red Line. London: BFI, 2004. Print.

Critchley, Simon. "Calm: On Terrence Malick's The Thin Red Line." Film-Philosophy 6.1 (2002). Web. 26 Jan. 2012.

Freud, Sigmund. Civilization and its Discontents. Trans. James Strachey. 1961. London: Norton, 1989. Print.

---. Totem and Taboo. Trans. James Strachey. 1950. London: Norton, 1989. Print.

Furstenau, Marc and Leslie MacAvoy. “Terrence Malick's Heideggerian Cinema: Warn and the Question of Being in The Thin Red Line." The Cinema of Terrence Malick: Poetic Visions of America. Ed. Hannah Patterson. London: Wallflower, 2003. 173-85. Print. 
Graves, Robert. The Greek Myths: The Complete and Definitive Edition. 1955. London: Penguin, 2011. Print.

Heidegger, Martin. "What Are Poets For?” Poetry, Language, Thought. Trans. Albert Hofstadter. New York: Harper, 1971. 91-142. Print.

Jones, James. The Thin Red Line. 1962. New York: Delta, 1998. Print. Malick, Terrence. The Thin Red Line. Dir. Terrence Malick. Perf. James Caviezel, Sean Penn, Nick Nolte. Twentieth Century Fox, 1998. Film.

Parsons, William B. The Enigma of the Oceanic Feelings: Revisioning the Psychoanalytic Theory of Mysticism. New York: Oxford UP, 1999. Print. Silverman, Kaja. Flesh of My Flesh. Stanford: Stanford UP, 2009. Print. Sinnerbrink, Robert. "A Heideggerian Cinema? On Terrence Malick's The Thin Red Line." Film-Philosopby 10.3 (2006): 26-37. Web. 26 Jan. 2011. 